\title{
An Investigation of the Democratic Values, Problem-Solving Skills, and Attitude Levels toward Violence of Secondary School Students
}

\author{
Adnan Özbey ${ }^{1}$ \\ ${ }^{1}$ Freelance Researcher, New Jersey, USA \\ Correspondence: Dr. Adnan Özbey, Freelance Researcher, New Jersey, USA.
}

Received: February 8, 2021

Accepted: April 19, 2021

Available online: April 23, 2021

doi:10.11114/ijsss.v9i3.5220

URL: https://doi.org/10.11114/ijsss.v9i3.5220

\begin{abstract}
The main objective of this study is to examine the possible relationship between democratic values, problem-solving skills, and attitudes toward violence. In addition, it studies whether democratic values, problem solving skills and the tendency of attitudes toward violence differ according to different variables. Descriptive model was used in the research. The study group of the study consisted of a total of 326 students, 172 female and 154 male selected by appropriate sampling from three middle schools in Konya. It was used Basic Democratic Values Questionnaire, Problem Solving Inventory for Children, and the Adolescents' Attitudes Toward the Violence in the study. While the data were analyzing, $\mathrm{t}$ test, ANOVA test, Pearson Moment Product Correlation analysis and simple linear regression analysis were used. When the data obtained from the research were examined, there was a significant difference in the level of attitudes toward violence according to the gender variables. There was a significant difference in problem solving skills and attitudes toward violence according to grade variables. Pearson's correlation analysis revealed statistically significant and negative relationship between democratic values, problem-solving skills, and attitudes toward violence. As a result of simple regression analysis, democratic values have predictive role on problem solving skills; it is seen that problem-solving skills are important variables in the tendency towards violence.
\end{abstract}

Keywords: democratic values, problem-solving skills, violence, attitudes toward violence

\section{Introduction}

The value of human life is above all other values. Therefore, states, societies, religions and religious texts become important to the extent that they take humanity to the highest level through learning, culture, and economic well-being, physical and mental health. It is for the development and peace of humanity that civilizations have institutions of different types. Humanity goes through various stages and periods, the number of theories on this subject proliferate, and these theories are frequently included in various arrangements (Sharma, 2015). For this purpose, since antiquity, there has been a consistent debate on "What values create a good life?" and the importance, nature, and scope of values have been emphasized (Veugelers, 2010). Some researchers highlighted values such as democracy, justice, citizenship, forgiveness, equality, and respect for life, freedom, cooperation, acceptance of differences, security, peace, and taking into account social life.

Democracy, in general, can be defined as a form of government where citizens determine their representatives through free and fair elections, policies that encourage economic and social development are implemented, which can ensure order, and that are based on the rule of law, democratic rules and respect for human rights (Abrahams \& Smith, 2011; Linde \& Ekman 2003). Democracy, in addition to being a concept that creates and maintains itself with the social elements, formal processes and practices it contains, also points to a way of thinking and a lifestyle connected to it (Yazgan, 2013). For this reason, one of the preconditions of democracies / democratic societies is the existence of participatory individuals who do not see their own opinions and thoughts as absolute truth, accept different world views, have a critical and questioning mindset, an understanding of social relationships based on respect and trust, and act with a sense of responsibility (Norris, 2011; Slev, 2014; Yesil, 2002). This characteristic of democracy shows that it is not a static concept, but a dynamic, active and changing process. In all key elements of democracy, the citizen or the individual appears to be one of the basic elements. Thus, democracy has a direct relationship with all areas of life, especially education (Saracaloglu et al. 2013).

Raising citizens with the qualifications required by democracy, ensuring the adaptation of individuals to the social 
structure, and helping them find a place in the social structure in line with their interests and abilities while this process is taking place, are among the basic tasks of the education system (Basaran 1987; Yazici, 2011). Especially in a period when beliefs and values are open to exploitation, the importance of education has increased for the existence and sustainability of democracy (Davis, 2010). Schools have a key place in education for democratic citizenship and human rights, as they play a role in bringing all these values to individuals and developing them through social learning opportunities utilizing structured and formal education programs (Gafoor, 2015; Tamer, 2011). However, education is not the only source of establishing a democratic culture; family, media, other institutions and every environment in which people live contribute to this process (Elkatmis \& Toptas, 2015; Subba, 2014).

Democratic values set forth the basic principles of democratic governance by separating democratic and non-democratic processes from each other. Democratic values include building trust through proactive communication, empowering individuals, making individuals adopt citizenship values in different ways, and increasing accountability and responsibility (Suleiman, \& Moore, 1996). For this reason, democratic values should not only consist of appearance for students, it should also be aimed for students to grasp the spirit of democratic values. Students should gain the ability to understand democratic values in terms of social justice and equality, and to internalize real-world issues in a way that they can meaningfully participate in discussions and decision-making processes. Another important element is to teach students to learn to respect democratic values. Learning democracy means combining the values of democracy, applying the requirements of democracy in daily life, being active, and taking risks in this sense (Subba, 2014). In this context, although there is no consensus on democratic values that should be gained; independence, freedom, self-esteem, self-confidence, tolerance, respect for human rights, a social state, respect for the right to life, avoidance of violence, dialogue, peace, friendship, helpfulness, critical thinking, solidarity, sensitivity, cooperation, equality, honesty, accountability, justice, political pluralism, acceptance of differences, respect for the environment, development, security, rule of law, active participation, freedom of expression, avoiding deception, preventing discrimination, finding peaceful solutions to conflicts, and respect for international human rights are generally considered among democratic values (Kincal and Isik, 2003; Moller, 2006; Ulusoy, 2007; Yesil, 2002).

Learning environments in democratic schools should have the qualities to equip students with the necessary competencies for solving real-life problems (Greiff et al. 2013; Sisman \& Donmez, 2010). Especially in middle childhood, children who start to spend more time with their peers need to carry many behavioral skills such as developing healthy communication, being included in a group, a sense of belonging, and resolving interpersonal conflicts (Uzunkol, 2014). Considering that it is not possible to live a problem-free life, the effects of problem-solving skills of individuals on their lives, the importance, and necessity of problem-solving skills is better understood (Cesit, Ece \& Kafadar, 2012).

A problem is a state of difficulty, conflict, limitation, imbalance, incompatibility, and uncertainty in the individual and society (Dostál, 2015; Kalayci 2006). Problem-solving is defined as an effective cognitive-behavioral process that involves the individual or group trying to discover solutions for certain problems encountered in daily life, developing goals, and choice among options (Chang, D'Zurilla \& Sanna, 2004; Heppner \& Baker 1997). The problem-solving process employs intelligence effectively and develops thinking and criticizing skills as a result of understanding, interpreting, evaluating, and applying the environment, relationships, and causes (Bakioglu et al., 2015; Yuksel, 2008). Generally, although problems are accepted as challenging and complex situations that disturb the individual and prevent him from achieving his goal (Adair, 2000; Begde \& Ozyurek, 2016), problem-solving can be considered as a process of adaptation to life and society. Some researchers suggest that problems should be considered not as adversities and difficulties, but as opportunities (Sahin, 2004). Children who solve their problems feel confident in themselves, make the right decisions and are willing to take risks (Brown 1988; Sanli, 2005). The problem-solving skill positively affects the social adaptation and success of the individual in daily life, helps the individual to gain resistance and maintain a balanced harmony by using his / her coping skills against difficulties (Sardogan et al. 2006). This is so because, it is observed in the relevant literature that individuals who can effectively solve their problems have higher self-esteem, perception of competence, and decision-making skill levels (Arenofsky, 2001; Hamarta, 2009); better psychological and physical health and professional achievements (Heppner, Witty, \& Dixon, 2004); and are more successful in interpersonal relationships and academic life than other individuals (Chang, 1998). On the other hand, it has been observed that individuals with poor problem-solving skills, compared to individuals with effective problem-solving skills, are inadequate in understanding others' expectations, experience more emotional problems and social anxiety, and are insecure (Sahin, Sahin \& Hepner, 1993). It has been determined that young people with a low level of aggression use problem-solving skills more, while those with a high level of aggression prefer to use avoidance more (Korkut, 2003).

Violence is expressed as a phenomenon that varies according to a certain period, social environment / structure, and special conditions (Debarbieux, 2009). According to a comprehensive definition, violence is the practice of physical 
force or threat against an individual, a person, a group, or a community that will result in injury, death, psychological harm, growth retardation, and disorders or breakdown (WHO, 2002; Mian, 2004). In addition to the use of force in violence, all words, approaches, attitudes, and actions that reflect aggression, physical or mental influences are important (Ozgur et al., 2011). Violence can be classified according to the environment in which it occurs as in domestic, sexual, traffic, street, institutional (mobbing), school (bullying, etc.), and media (Sam et al.2016). Violence in schools is defined as an attempt to harm students emotionally or physically or to harm the school environment, school, or students' belongings (Benbenishty and Astor 2005; Capp et al., 2017). Research findings on school violence indicate factors such as depression, antisocial beliefs, attitudes, and behaviors (Hawkins et al., 2000; Kim, Capaldi, 2004); exposure to domestic and community violence and conflict (Button, 2008; Copeland-Linder et al., 2012; Fowler et al., 2009); authoritarian child-raising attitudes of parents and loose or inconsistent discipline practices (Chaffin, 2006); violent behavior learned through various media (TV, news, movies, video games, etc.) (Anderson et al., 2010; Huesmann , 2007; Guttman et al., 2006; Nader, 2010; Wang et al., 2006); poor or worsening school performance and learning difficulties; and an inability to set goals, a relationship with gangs, intolerance to differences, not accepting the rights of others, untimely expression of thoughts, drug or alcohol abuse, uncontrollable anger, and ethnicity (Bulach et al., 2003; Grunseit et al., 2005; Larose \& Tarabulsy, 2015; Osofsky \& Osofsky, 2001) are the sources of violence observed in adolescents and experienced in school. Personal tendencies, beliefs that view violence as natural, a lack of social skills, and involvement in violence at an early age are listed among personal factors (Durmus, 2013).

According to Ogulmus (2006), the issue of violence in schools is a multi-dimensional problem and can be associated with many factors. For example, it can be related to immigration and unemployment. The loss of functions of traditions due to internal migration, the gradual decrease of adult supervision and control over children, and the changes in family structure, such as children starting to work at an early age, are among these reasons. Similarly, the fact that children start earning money at an early age and that they feel like "adults" negatively affects them. The child cannot develop his/her social skills while he/she is away from school. Accordingly, a profile of a young individual more open to the influence of peer groups emerges; thus, causing him/her to leave school, adopt some negative habits such as becoming involved in gangs, alcohol and drug abuse.

\section{Significance of Research}

Globalization, the dynamics that direct social changes such as democratization and modernization, require individuals to display democratic attitudes and behaviors while democratizing governance structures. The acquisition of democratic skills that require human maturity is not accidental or spontaneous. The main actor that serves the construction of a democratic and contemporary world is undoubtedly institutional education (Elkatmis \& Toptas, 2015). However, the methods that can be used to solve the problems in interpersonal relationships in schools are not taught as a course, and the majority of the problems in schools are unfortunately solved by the method of solving problems by using force, which is known as a bad problem-solving method, and which is unfortunately settled in traditions long ago (Ogulmus, 2001). Adolescents who use anger and violence as a coping method in solving their problems have a much higher tendency towards violence (Flannery, 1997).

21st-century skills and values are educational qualities that are also expressed as global competencies or life skills (Binkley et al.2010). This competence is more than knowledge or skill. It covers theory, concepts, and knowledge, as well as technical skills, social or organizational skills, and ethical values (Cedefop, 2014). It includes the ability to meet complex demands by attracting and mobilizing psychosocial resources (including skills and attitudes) in a particular context (OECD, 2003). It is possible to classify 21st-century skills as learning and innovation skills, communication skills, knowledge, media and technology skills, life, and career skills. While problem-solving skills are included in learning and innovation skills, skills that can be expressed as qualities of democratic life such as sensitivity, violence-free living, flexibility, adaptability, and responsibility are considered life and career skills (P21, 2007).

When the related literature about democracy and democratic values is examined, democracy education (Guven, 2009); primary school students' perceptions of democracy (Kus \& Cetin, 2014); the relationship between secondary school students' tolerance tendencies and their perception of democracy (Bektas-Oztaskin \& Icen, 2015); high school students' perceptions of democratic school culture (Kabasakal et al., 2015); democracy education and the democratic behavior of high school students (Diker, 2012) and similar other studies are found. Regarding problem-solving skills, secondary school students' problem-solving and logical thinking skills (Koray \& Azar, 2008); primary school students' perceptions of their problem-solving skills and their seeking help in the learning process (Koc, 2016); problem-solving, cognitive awareness and epistemological beliefs in primary 6th, 7th and 8th-grade students (Saban \& Yüce, 2012); determination of high school students' perceptions of problem-solving skills (Sezen \& Palic, 2011); the examination of adolescents' interpersonal problem-solving skills and tendencies of empathy in terms of their values (Demir 2017); effect of interpersonal problem-solving skills training on their constructive problem-solving and trait anger levels (Bedel \& Ari, 2012); and similar other studies have been observed. Regarding the attitude towards violence, studies such as the 
phenomenon of violence in education, the relationship of violence, aggression and moral attitude in high school students (Avci, 2010); familial factors affecting adolescents' tendency to violence (Gencoglu, Kumcagiz \& Ersanli, 2014); the role of human values in predicting trait anger and anger expression in adolescents (Karababa \& Dilmac, 2015); high school students' perceptions of violence, violence tendency levels and affecting factors (Ozgur et al., 2011); the relationship between adolescents' trait anger expression styles and their problem-solving skills (Danisik, 2005); and the relationship between secondary school students' tendency towards violence and their school engagement levels (Saglam \& Ikiz, 2017) are found. However, no study is available that handles the concepts of democratic values, problem-solving skills, and attitudes towards violence together. It is thought that such research is needed in the related field. The research conducted for this purpose is expected to contribute to the field with its results.

The main purpose of this study is to determine middle school students' democratic values, problem-solving skills, attitudes towards violence, and the possible relationship among them. Furthermore, the study aims to see whether democratic values, problem-solving skills, and attitudes towards violence differ according to different variables. For this purpose, answers were sought for the following questions:

i) Do middle school students' democratic values, problem-solving skills, and attitudes towards violence differ statistically significantly by the gender variable?

ii) Do middle school students' democratic values, problem-solving skills, and attitudes towards violence differ statistically significantly by the grade variable?

iii) Is there a statistically significant relationship between middle school students' democratic values, problem-solving skills, and attitudes towards violence?

iv) Does the level of democratic values of secondary school students statistically significantly predict their problem-solving skills?

v) Do middle school students' problem-solving skills predict their attitudes towards violence in a statistically significant way?

\section{Method}

The correlational survey model, which is a subtype of the general survey model, was used in this study. General survey models are research approaches that aim to describe a past or present situation as it is. Correlational survey models are research models that aim to determine the relationship between two or more variables, the existence and/or degree of covariance (Karasar, 2012). This study aims to determine the possible relationship between democratic values, problem-solving skills, and attitudes towards violence.

\section{Study Group}

The study group of the research was formed considering ease of access and applicability. For this purpose, $6^{\text {th }}, 7^{\text {th }}$, and $8^{\text {th }}$ grade secondary school students attending three different private schools $((92,28.7 \%)+(97,29.6 \%)+137,41.8 \%)$ were included in the study. In the first stage, the scales were evaluated separately, and six students whose scales were missing or incorrect were excluded from the sample. As a result, the scores of a total of 326 middle school students, 172 $(53 \%)$ female students and $154(47 \%)$ male students were evaluated for the study group. The ages of the students varied between 11 and 14 and the average age was 12.96 .

\section{Data Collection Tools}

The Problem-solving Inventory for Children was developed by Heppner \& Peterson (1982) to measure the problem-solving levels of children. The scale was adapted to the Turkish culture by Serin, Serin, and Saygili (2010), and consists of 24 items and three sub-dimensions (1st Dimension: Trust in Problem-solving Skills; 2nd Dimension: Self-Control; 3rd Dimension: Avoidance). The confirmatory factor analysis applied for the construct validity revealed that the data fit of the model consisting of three sub-dimensions (Confidence in Problem-solving Skills, Self-Control, and Avoidance $)$ and the 24 items was acceptable $(\chi 2=621.05, \mathrm{df}=249, \chi 2 / \mathrm{df}=2.49, \mathrm{RMSEA}=0.051, \mathrm{NNFI}=0.87$, $\mathrm{CFI}=0.90$, GFI $=0.92$, and AGFI $=0.90$ ). The correlation calculated between the problem-solving scores was 0.741 $(\mathrm{p}<0.001)$ for the $1^{\text {st }}$ factor, $0.679(\mathrm{p}<0.001)$ for the $2^{\text {nd }}$ factor, and $0.478(\mathrm{p}<0.001)$ for the $3^{\text {rd }}$ factor. The internal consistency reliability coefficients of the scale were calculated as 0.84 for the $1^{\text {st }}$ factor, 0.79 for the $2^{\text {nd }}$, and 0.70 for the $3^{\text {rd }}$ factor, respectively, for the three sub-dimensions, and 0.85 for the whole scale. Items in the "Self-Control" dimension $(2,4,6,8,10,12$, and 14) and items in the "Avoidance" dimension $(16,18,20,22$, and 24) are negative (reverse) items. In this study, the Cronbach's alpha internal consistency coefficient of the scale was calculated as 0.89 for the whole scale.

Basic Democratic Values Scale was developed by Uygun and Engin (2014) to measure the democratic values of individuals, and is a 5-point Likert-type scale. The exploratory factor analysis was used in the scale development study, 
its criterion validity study was performed, the item distinctiveness values were determined, and the Cronbach's alpha reliability value was calculated. As a result of the confirmatory factor analysis applied for construct validity, it was seen that the data fit of the model was acceptable $(\chi 2=122.35, \mathrm{df}=28, \chi 2 / \mathrm{df}=4.36, \mathrm{RMSEA}=0.08, \mathrm{RMR}=0.35, \mathrm{SRMR}=0.03$, $\mathrm{GFI}=0.96$, AGFI $=0.91$ and $\mathrm{CFI}=0.99)$. At the end of the study, a scale consisting of 34 items and 4 sub-dimensions $\left(1^{\text {st }}\right.$ dimension: cooperation (10 items), $2^{\text {nd }}$ dimension: self-confidence $\left(8\right.$ items), $3^{\text {rd }}$ dimension: respect for differences $(8$ items) and $4^{\text {th }}$ dimension: fairness ( 7 items)) was obtained. Regarding the Cronbach's alpha coefficients, the internal consistency coefficient was calculated as 0.77 for the "cooperation" sub-dimension, 0.69 for the "self-confidence" sub-dimension, 0.63 for the "respect for differences" dimension, and 0.56 for the "fairness" sub-dimension. The total scale reliability coefficient was calculated as 0.82 . In this study, the Cronbach's alpha internal consistency coefficient of the scale was calculated as 0.89 for the whole scale.

The Attitudes Towards Violence Scale for Adolescents was developed by Cetin (2011) to measure adolescents' attitudes towards physical violence. It is a 5-point Likert-type scale and consists of 10 items and a single factor. Item-total correlation values of the items in the scale range between 0.47 and 0.67 . The exploratory factor analysis was used in the scale development study, its criterion validity study was performed, the item distinctiveness values were determined, and the Cronbach's alpha reliability value was calculated. As a result of the confirmatory factor analysis applied for construct validity, it was seen that the data fit of the model was acceptable $(\chi 2=116.44, \mathrm{df}=35, \chi 2 / \mathrm{df}=4.36$, RMSEA=0.06 RMR=0.037, SRMR=0.037, GFI=0.96, AGFI=0.94. CFI=0.95, IFI:0.91, RFI:0.91). The Cronbach's alpha reliability coefficient for 10 items of the scale was found to be 0.85 . In this study, the Cronbach's alpha internal consistency coefficient of the scale was calculated as 0.88 for the whole scale.

\section{Procedure}

In this study conducted with the correlational survey technique, the variables of democratic values, problem-solving skills, and attitude towards violence were carefully selected to determine the possible relationship. Then, the scales related to the variables, and personal data forms were brought together to obtain the main variables. The necessary permissions were obtained for the application form, and applications were made through school counselors and administrators. Before starting the scale application, the children were informed about the importance of the application, asked whether they were willing to volunteer, and then the application was conducted with the students who volunteered to participate. After, the data obtained were transferred to the computer environment and were analyzed with parametric tests (Kurtosis and skewness values were between -1 and +1 ). The SPSS package program was used for statistical analysis. The independent samples t-test and ANOVA test were used for paired comparisons, the Pearson's product-moment correlation analysis was used to determine the relationships between variables, and the simple linear regression analysis was used to determine the predictive level. A p-value below a significance level of 0.05 was taken as the confidence interval.

\section{Findings and Analysis}

\section{Comparative Analyses}

The Kolmogorov-Smirnov statistic value was determined as 0.69 ( $p>0.05)$ for the problem-solving skills scores, 0.062 ( $>0.05$ ) for the attitude scores towards violence, and 0.56 ( $p>0.05$ ) for the democratic values scores. The skewness and kurtosis values for problem-solving skills, attitude towards violence, and democratic values scores were found to be between +1 and -1 . Considering both Kolmogorov-Smirnov statistical values and skewness and kurtosis values, it can be said that the data are fit for normal distribution. Therefore, an independent sample t-test was used to compare the problem-solving skills, attitudes towards violence, and democratic values of middle school students by the gender variable, and the findings are shown in Table 1.

Table 1. T-Test Results of Democratic Values, Problem-solving Skills, and the Attitude towards Violence by the Gender Variable

\begin{tabular}{lllllll}
\hline & Gender & $\boldsymbol{N}$ & $\bar{X}$ & $\boldsymbol{S D}$ & $\boldsymbol{t}$ & $\boldsymbol{p}$ \\
\hline Democratic Value & Female & 172 & 38.76 & 0.5199 & \multirow{2}{*}{. } & \multirow{2}{*}{0.149} \\
Problem-solving & Male & 154 & 39.54 & 0.4385 & & \\
\multirow{2}{*}{ Attitude Towards Violence } & Female & 172 & 34.85 & 0.6365 & \multirow{2}{*}{0.656} & 0.512 \\
& Male & 154 & 34.39 & 0.6268 & & \\
& Female & 172 & 23.96 & 0.8648 & -3.914 & 0.000 \\
\hline
\end{tabular}

*p $<0.05$ 
As seen in_Table 1, there is no statistically significant difference between_female students' democratic value score averages $(X=38.76)$ and male students' democratic values mean scores $(X=39.54)(t=-1.447, p<0.05) \rightarrow$ Similarly, there is no statistically significant difference between female students' problem-solving skills mean score ( $\mathrm{X}=34.85$ ) and male students' problem-solving skills mean score $(X=34.39)(t=0,656, p<0.05)$. On the other hand, the mean scores of male students attitudes towards violence $(X=28.09)$ are statistically significantly higher than those of female students attitudes towards violence $(X=23.96)(t=-3.914, p<0.05)$.

The ANOVA test was used to compare middle school students' democratic values, problem-solving skills, and attitudes towards violence by the class variable, and the findings are shown in Table 2.

Table 2. The ANOVA Test Results of Democratic Values, Problem-solving Skills, and Attitude towards Violence by the Grade Variable

\begin{tabular}{|c|c|c|c|c|c|}
\hline & Source & & & $\mathbf{F}$ & $\mathbf{p}$ \\
\hline \multirow[t]{3}{*}{ Democratic Values } & Intergroup & 0.337 & 0.168 & & \\
\hline & Within Groups & 75.619 & 0.235 & 0.717 & 0.489 \\
\hline & Total & 75.956 & & & \\
\hline \multirow[t]{3}{*}{ Problem-solving } & Intergroup & 8.452 & 4.226 & & \\
\hline & Within Groups & 120.730 & 0.375 & 11.271 & 0.000 \\
\hline & Total & 129.182 & & & \\
\hline \multirow[t]{3}{*}{ Tendency to Violence } & Intergroup & 12.884 & 6.442 & & \\
\hline & Within Groups & 227.763 & 0.799 & 8.061 & 0.000 \\
\hline & Total & 240.646 & & & \\
\hline
\end{tabular}

$* \mathrm{p}<0.05$

As seen in the table, problem-solving skills and scores of attitude towards violence differ significantly by the grades students attend. The Scheffe test was conducted to determine the groups that caused a significant difference (Table 3). The Scheffe test was used because it creates homogeneous subtests and is sensitive to alpha-type errors.

Table 3. The Scheffe Test Results of Problem-solving Skills, Attitude towards Violence Scores by the Grade Variable

\begin{tabular}{llllll}
\hline & 7th Grade & $\mathbf{N}$ & $\bar{X}$ & Value & p \\
\hline Problem-solving & $6^{\text {th }} 7^{\text {th }}$ Grade & 103 & 36.80 & $6>7^{*}$ & 0.017 \\
& $7^{\text {th }}$ Grade & 111 & 34.40 & $7<8$ & 0.173 \\
& $8^{\text {th }}$ Grade & 112 & 32.86 & $8<6^{* *}$ & 0.000 \\
Attitude Towards Violence & $6^{\text {th }} 7^{\text {th }}$ Grade & 103 & 22.20 & $6<7^{*}$ & 0.021 \\
& $7^{\text {th }}$ Grade & 111 & 26.10 & $7<8$ & 0.380 \\
& $8^{\text {th }}$ Grade & 112 & 27.77 & $8>6^{* *}$ & 0.000
\end{tabular}

$* \mathrm{p}<0.05, * * \mathrm{p}<0.01$

As seen in Table 3, the total mean problem-solving scores of the sixth graders $(\bar{X}=36.80)$ are statistically significantly higher than those of the seventh graders $(X=34.40)$ and the eighth graders ( $X=32.86)$. Furthermore, seventh-graders' total mean_scores of attitude towards violence $(X=26.10)$ and eighth-graders' total mean scores of attitude towards violence $\left(\frac{X}{X}=27.77\right)$ are statistically significantly higher than the sixth graders' total mean scores of attitude towards violence $(X=22.20$ ).

\section{Findings on Relationships}

In order to determine the relationships between democratic values, problem-solving skills, and attitudes towards violence, a correlation analysis was conducted, and the results are given in Table 4. 
Table 4. Pearson's Correlation Matrix Showing the Relationships between Democratic Values, Problem-solving Skills, and Attitudes towards Violence

\begin{tabular}{lllllll}
\hline Variables & N & DV & PSS & ATV & X & SD \\
\hline 1. Democratic Values & 326 & - & $561^{* *}$ & $-0.210^{* *}$ & 39.12 & 48.41 \\
2. Problem-solving & 326 & & - & $-0.389^{* *}$ & 34.63 & 63.14 \\
3.Attitude Towards Violence & 326 & & & - & 25.87 & 91.56 \\
\hline
\end{tabular}

$* * \mathrm{p}<0.01$

As seen in Table 4, there are statistically significant positive correlations between democratic values, problem-solving skills, and attitude towards violence at the threshold of $\mathrm{p}<0.01$. Accordingly, the correlation coefficient was determined as $\mathrm{r}=0.56$ between democratic values and problem-solving skills; as $\mathrm{r}=-0.39$ between problem-solving skills and attitude towards violence; and as $\mathrm{r}=-0.21$ between democratic values and attitude towards violence.

A simple linear regression analysis was performed to see the role of the democratic values variable in predicting problem-solving skills, and the results are shown in Table 5.

Table 5. The Multiple Regression Analysis Table for the Relationship Value between Democratic Values and Problem-solving Skills $(\mathrm{N}=326)$

\begin{tabular}{llllll}
\hline Model & B & SH & $\beta$ & $\mathrm{t}$ & $\mathrm{p}$ \\
\hline (Constant) & 0.598 & 0.238 & & 2.513 & 0.012 \\
Democratic Values & 0.733 & 0.060 & 0.561 & 12.153 & 0.000 \\
\hline
\end{tabular}

$* \mathrm{p}<0.05, * * \mathrm{p}<0.01$

As a result of the simple linear regression analysis, a moderate and positive significant relationship was found between democratic values and problem-solving skills $(\mathrm{R}=56, \mathrm{R} 2=0.31, \mathrm{p}<0.01)$. Accordingly, democratic values explain $31 \%$ of the total variance in the problem-solving variable. When the standardized $(\beta)$ coefficient and $t$ values are examined, it can be said that democratic values are a significant predictor.

A simple linear regression analysis was performed to see the role of problem-solving skills in predicting the level of attitude towards violence, and the results are shown in Table 6.

Table 6. The Multiple Regression Analysis Table for the Relationship Value between Problem-solving Skills and Attitude Towards Violence $(\mathrm{N}=326)$

\begin{tabular}{llllll}
\hline Model & B & SH & $\beta$ & $\mathrm{t}$ & $\mathrm{p}$ \\
\hline (Constant) & 4.663 & 0.294 & & 15.837 & 0.000 \\
Problem-solving Skills & -0.604 & 0.085 & -0.389 & -7.139 & 0.000 \\
\hline
\end{tabular}

$* \mathrm{p}<0.05, * * \mathrm{p}<0.01$

As a result of the simple linear regression analysis, a negative and significant relationship was found between problem-solving skills and attitude towards violence $(\mathrm{R}=389, \mathrm{R} 2=0.15, \mathrm{p}<0.01)$. Accordingly, problem-solving skills explain $15 \%$ of the total variance. When the standardized $(\beta)$ coefficient and t values are examined, it can be said that problem-solving skills are a significant predictor.

\section{Discussion and Conclusion}

The main purpose of this study is to determine the level of the relationship between democratic values, problem-solving skills, and attitudes towards violence, as well as to determine whether democratic values, problem-solving skills, and attitudes towards violence differ by some variables. For this purpose, answers were sought for some questions.

For the first question of the study, it was tested whether democratic values, problem-solving skills, and attitudes towards violence differed by gender. According to the results of the study, democratic values scores do not have a statistically 
significant difference by the gender variable. Some studies in the related field (Ada \& Koc, 2000; Bulut, 2006; Kilic, Doganay, Cuhadar \& Sari, 2004; Elkatmis \& Toptas, 2015; Ercoskun \& Nalcaci, 2004; Saracaloglu et al., 2013; Karahan et al., 2006; Karaman-Kepenekci, 2006; Sam et al., 2016; Yazici, 2011) supports the findings of the current research. According to these studies, girls and boys have similar characteristics in terms of democratic attitude. This outcome shows that both genders have grown up in similar social conditions in terms of democracy culture and democratic life (Karahan et al., 2006; Naziroglu \& Cetin, 2014). According to Elkatmis and Toptas (2015), it can be thought that the gender variable is not clear enough to reflect democratic attitudes because there are research findings at a level that can be considered equal to represent both groups in the relevant field. In this context, many studies can be found that do not support the findings of the research (Bektas-Oztaskin, \& Icen, 2015; Diker, 2012; Kus \& Cetin, 2014; Sarialtin, Ataizi \& Server, 2017; Tekin \& Gullu, 2010). These studies mostly show differences in favor of female students. This result suggests that female students are more democratic than male students are, or they understand and adopt democratic values better. According to the other findings of the study, although female students' problem-solving skills scores are higher than male students, they are not statistically significant. This result is consistent with the result of the study reporting that the gender variable does not affect the development of problem-solving skills (Canan, 2016; Cevik, 2011; Cevik \& Ozmaden, 2013; Gucray, 2003; Guven, 2010; Saracaloglu et al., 2009; Yenice et al., 2012; Yildirim \& Yalcin, 2008). On the other hand, studies that conclude that there is a significant relationship between gender and problem-solving skills scores are also available. Some of these studies found that girls (Sezen \& Palic, 2011; Serin \& Derin, 2008; Yildirim et al., 2011) had higher problem-solving skills, while some (Korkut, 2002; Koray \& Azar, 2008) found that boys' problem-solving skills were more developed. These results suggest that gender is not an absolute predictor that can affect problem-solving skills (Yildirim et al., 2011). According to Cevik (2011), gender roles and the individual's sense of trust may cause a difference in problem-solving skills between men and women. As the roles and duties assigned to individuals in society are different, problem-solving skills may also vary. According to another result of the study, the attitude towards violence scores of male students were found to be statistically significantly higher than those of female students. According to this result, male students are more prone to violence than female students. Many studies supporting the research results can be found in the related field (Avci, 2010; Gencoglu et al., 2014; Ozgur et al., 2011; Saglam \& Ikiz, 2017). A known source of individual difference is the socialization difference between the genders. While men are encouraged from childhood to be more aggressive than women, women are prohibited from such behavior. Based on these results, the identification of violent and aggressive behaviors with the concept of masculinity and reinforcement of such aggressive behavior by praising or accepting from childhood and adolescence in male-dominated societies can be thought to cause men to be more prone to violence. Considering that, girls' behaviors such as obedience and remaining silent are more reinforced and encouraged in these societies; this result can be partially explained by the families' child-rearing styles and gender roles (Saglam \& Ikiz, 2017).

In the second question of the study, it was tested whether the levels of democratic values, problem-solving skills, and attitudes towards violence differed significantly by the grade variable. According to the analysis results, democratic values did not show a significant difference by the grade variable. The study results of Naziroglu \& Cetin (2014), Saracaloglu (1997), Saracaloglu et al. (2013), Tekin (2009), and Yazici (2011) support this finding. This insignificant difference can be due to a good school climate, learning processes, and democratic leadership behaviors of the instructors (Tekin, 2009). On the other hand, Serin (2006), Kus \& Cetin (2014) and Kabasakal et al. (2015) reported that democratic values differed by grades in their studies, and they reached conclusions that did not coincide with the findings of the present study. According to the other findings regarding the second question, the problem-solving skills of the sixth graders were statistically significantly higher than the problem-solving skills of the 7th and 8th graders. In this case, it can be said that sixth-graders believe that they will find effective solutions when they encounter a problem situation, have higher perceived levels of general problem-solving skills, and tend to avoid a problem compared to seventh and eighth graders (Koc, 2014). The high mean scores of the problem-solving skills of sixth-grade students can be explained by the fact that branch teachers become involved more intensively while students receive an education with the classroom teacher and therefore they may encounter many problems related to the process (Saban \& Yuce, 2012). Findings of Cevik (2011), Koc (2014), and Saban \& Yuce (2012) in the relevant field support the results of the present study. According to another finding regarding the second question, the seventh and eighth graders' levels of attitude towards violence are statistically significantly higher than those of the sixth graders. These results show that seventh and eighth graders are more prone to violence. This means that as the grades of students become higher, in other words, as they grow older, their violence orientation also increases (Ozgur et al., 2011). This result is in line with the results of Aydın, Ersoy \& Aktas, (2015), Ozgur et al. (2011) and Saglam and Ekiz (2017). However, there are also studies reporting that there is a positive significant relationship between the increase of students' grade levels and their anger control. It has been found that as the biological development, age, cognitive level, and learning experience of the students increase, they generally keep their anger under better control (Saglam, 2009). This result is not consistent with the research findings. 
In the third question of the study, it was tested whether there was a statistically significant relationship between democratic values, problem-solving skills, and attitudes towards violence. According to the test results, there is a positive and significant relationship between democratic values and problem-solving skills. Accordingly, the problem-solving skills of individuals who have democratic values and grow up in a democratic family and educational atmosphere also improve. There are no studies directly supporting the research findings in the relevant field however, it is seen that this relationship is indirectly included in some studies. Demir (2017) observed that there is a positive relationship between the values of adolescents and their interpersonal problem-solving skills. Altun (2003) found that individuals who consider human dignity as the most important value are the most successful in problem-solving. A democratic attitude, in which the behaviors are temperate and consistent, allows the child's personality to develop in a balanced way (Gungor, 2013). Seeking answers to the problems faced by these individuals within the framework of democratic rules plays an important role in making society healthier and more respectful to each other (Genc \& Kalafat, 2007). Boldwin (1995) determined that children raised in a family environment where a democratic attitude prevails have positive personality traits, children raised in families with an authoritarian attitude have a very unstable state of mind, difficulty in producing new ideas, and experience more fear and anxiety. According to the other result of the third question, democratic values have a significant negative relationship with the attitude towards violence. However, there is no study directly supporting the research findings in the related field. The research of Karababa \& Dilmac (2015) revealed a negative relationship between human values and trait anger, internalized anger, and externalized anger and conversely, a positive and significant relationship with controlled anger. In a different study, Avci (2010) found that there is a significant negative relationship between moral attitude, aggression and violence in adolescents. Karahan et al. (2006) found that students with low democratic attitude levels have higher neurotic tendencies than other students. The author stated that, in these students, neurotic tendencies, such as being easily resentful of criticism, frequently becoming angry with and being offended by people around them, general tension and distress, inability to concentrate, and psychosomatic complaints were more intense than in other students. According to another result of the third question, there is a significant negative relationship between students' problem-solving skills and their attitudes towards violence. Accordingly, individuals with high problem-solving skills are less likely to tend towards violence. Koc \& Kavas (2015) found a negative relationship between problem-solving and communication skills, and destructive aggression; Gundogdu (2010), between problem-solving and physical aggression; and D'zurilla, Chang \& Sanna (2003) and Sargin (2008) between aggression and social problem-solving. Kurtyilmaz (2005) stated that the more problem-solving skills are perceived to be insufficient, the more frequently aggression behaviors occur. Yarali \& Ozkan (2016) observed that as the social problem-solving skills of children increase, their anger-aggression behavior decrease.

For the fourth question of the study, the statistical predictive power of democratic values on problem-solving skills was tested. According to the findings, students having democratic values and being educated in democratic environments significantly increase their problem-solving skills. In democratic education, it is aimed to make individuals gain skills such as "electing and being elected, criticizing and being criticized, justice, sense of responsibility, sense of cooperation, friendship and self-confidence1" (Binbasioglu, 2000). The sense of freedom and individual responsibility developed with these skills helps students to discover what appropriate social behavior is and to resolve conflicts at school with non-coercive and collaborative methods (Ainsa, 2011). Therefore, it enables students to develop interpersonal problem-solving and social-emotional skills (Tkach, 2018). Otherwise, pressure-discipline negatively affects the psychosocial-based problem-solving skills of children. Parents and/or teachers with this attitude do not support the child's making decisions on his/her own. They may make all decisions on behalf of the child and solve problems instead of the child. Where pressure-discipline decreases, children's psychosocial-based problem-solving skills increase (Ari \& Secer, 2003). In this context, it is a probable result that the democratic values of students increase their problem-solving skills.

For the fifth question of the study, it was tested whether problem-solving skills statistically predicted attitude towards violence. Findings show that problem-solving skills significantly predicted attitude towards violence. Accordingly, individuals who acknowledge and share their feelings are expected to better control their violent tendencies, think healthier, and make more positive decisions in the face of problems, and therefore having higher problem-solving skills (Danisik, 2005). There are studies supporting the research findings in the relevant literature. According to the observations of Moon and Eisler (1983), developing problem-solving skills encourage individuals to interact competently with the environment and support the struggle against the factors that stimulate anger. According to Maddoux et al. (2014), insufficiencies in problem-solving skills lead to an increase in behavioral disorders in children. Bedel and Ari (2012) found that problem-solving skills significantly decreased adolescents' trait anger level; Cekici and Güçray (2012) determined that problem-solving skills positively affected "thoughts of anger towards the world" and this was a long-lasting effect. Oztaban and Adana (2015) reported in their study that the problem-solving skills acquired by high school students contributed to the control of anger and the positive development of interpersonal relationships, and this effect continued to increase in the long term. In another study, Cengiz and Ercan (2011) found that problem-solving 
skills significantly explained the level of aggression. The fact that the individual has a positive attitude towards the interpersonal problem he/she experiences and that he/she knows the logical problem-solving steps, have a significant effect on solving the problem and controlling the sense of anger regarding the problem. On the contrary, having a negative attitude towards the problems experienced and lack constructive problem-solving skills can negatively affect the ability to solve interpersonal problems, and can lead to the experience of emotions and behaviors such as intense anger and aggression (Bedel \& Ari, 2012).

In conclusion, a significant difference was found in the attitude levels towards violence by the gender variable. A significant difference was found in problem-solving skills and attitudes towards violence by the grade variable. While a positive relationship was found between democratic values and problem-solving skills, a negative and significant relationship was found between democratic values and problem-solving skills and attitude towards violence. Democratic values significantly boost problem-solving skills, and problem-solving skills significantly reduce the attitude towards violence. In other words, since students with democratic values have higher levels of problem-solving skills, they solve their problems without resorting to violence.

For this reason, first of all, appropriate democratic education models need to be developed, democratic environments should be established and democratic teachers should be trained for students to acquire democratic values and transform these values into behaviors in daily life; in other words, to transform the culture of democracy into a lifestyle.

\section{Limitations and Suggestions}

Problem-solving skills are cognitive skills that can be learned and developed and should be carefully emphasized in all areas of the educational process. According to the results of this study, studies can be conducted regarding the fact that students perceive their problem-solving skills more positively as their grade level / age increases.

To increase the democratic values and problem-solving skills of secondary school students, the activities in lessons can be reviewed by using the positive and meaningful relationship between them.

Problem-solving skills and violence-free living are among the top priority achievements of the $21^{\text {st }}$ century. In this context, students with a low level of problem-solving skills and a high tendency towards violence can be identified and these students can be offered training programs on cooperation, communication skills, interpersonal relationships, and effective problem-solving skills through psychological counseling and guidance services.

Although it is important to increase the awareness of all students about violence, it was found as a result of the research that boys have a higher disposition towards violence. For this reason, programs can be prepared for boys regarding violence and gender roles.

Considering the results obtained in this study, it is necessary to draw attention to some limitations before making a clear judgment. This study is limited to three different schools and sixth, seventh, and eighth grade students. From this point of view, it can be stated that the number of participants is insufficient. A study to be conducted in a way that covers larger samples by including different variables, with students from different schools and educational levels can bring other dimensions to the research.

\section{References}

Abrahams, M., \& Smith, J. (2011). A study of perceptions around democracy in six communities in the Umgungundlovu District Municipality, KwaZulu-Natal. Pietermaritzburg Agency for Christian Social Awareness (PACSA).

Ada, Ş., \& Koç, M. (2000). Üniversite öğrencilerinin lisans eğitimleri süresince demokratik tutumlardaki değişmelerin çeşitli değişkenler açısından incelenmesi. Ulusal Eğitim Bilimleri Kongresi, 27-30.

Adair J. (2000). Karar verme ve problem çözme. (Çev. Nurdan Kalaycı) Ankara: Gazi Kitabevi.

Ainsa, P. (2011). Critical pedagogy towards a sociomoral classroom. Journal of Instructional Psychology, 38(2), 84.

Altun, I. (2003). The perceived problem solving ability and values of student nurses and midwives. Nurse education today, 23(8), 575-584. https://doi.org/10.1016/S0260-6917(03)00096-0

Anderson, C. A., Shibuya, A., Ihori, N., Swing, E. L., Bushman, B. J., Sakamoto, A., Rothstein, H. R., \& Saleem, M. (2010). Violent video game effects on aggression, empathy, and prosocial behavior in Eastern and Western countries: a meta-analytic review. Psychological Bulletin, 136(2), 151-73. https://doi.org/10.1037/a0018251

Arı, R., \& Seçer, Z. Ş. (2003). Farklı ana baba tutumlarının çocukların psikososyal temelli problem çözme becerilerine etkisinin incelenmesi." S.Ü. Sosyal Bilimler Enstitüsü Dergisi, 10, 451-456.

Avc1, A. (2010). Eğitimde şiddet olgusu lise ögrrencilerinde şiddet, saldırganlık ve ahlakî tutum ilişsisi (Küçükçekmece İlçesi Örneği). Yayımlanmamış Doktora Tezi, Marmara Üniversitesi, Sosyal Bilimler Enstitüsü, İstanbul. 
Aydın, P., Ersoy, A., \& Aktaş, N. (2015). Aktif Spor Yapan ve Yapmayan 12-14 Yaş Ortaokul Öğrencilerinin Şiddet Eğilimlerinin İncelenmesi. Sportif Bakış: Spor ve Eğitim Bilimleri Dergisi, 2(1), 1-9.

Bakioğlu, B., Küçükaydın, M. A., \& Karamustafaoğlu, O. (2015). Öğretmen adaylarının biliş̧̈tesi farkındalık düzeyi, problem çözme becerileri ve teknoloji tutumlarının incelenmesi. Trakya Üniversitesi Eğitim Fakültesi Dergisi, 5(1).

Baldwin, A. L. (1995). Behaviour and Development Childhood (2nd ed.). The Diyder Pres. NewYork.

Başaran, İ. E. (1987). Demokrat öğrenci nasıl yetiştirilir. Ankara Üniversitesi Eğitim Bilimleri Fakültesi Dergisi, 19(1-2), 111-116. https://doi.org/10.1501/Egifak_0000001098

Bedel, A., \& Arı, R. (2012). Kişiler arası sorun çözme beceri eğitiminin ergenlerin yapıcı problem çözme ve sürekli öfke düzeylerine etkisi. Ilköğretim Online, 11(2).

Begde, Z., \& Özyürek, A. (2016). Öğretmen ve anne-baba tutumlarının okul öncesi dönem çocuklarının problem çözme becerilerine etkisi. Amasya Üniversitesi Ĕgitim Fakültesi Dergisi, 5(1), 204-232.

Bektaş-Öztaşkın, Ö., \& İçen, M. (2015). Ortaokul öğrencilerinin hoşgörü eğilimleri ile demokrasi algıları arasındaki ilişkinin incelenmesi. Giresun Üniversitesi sosyal bilimler enstitüsü Karadeniz sosyal bilimler dergisi, Hüseyin Hüsnü Tekışılk özel saylsı, 1, 39-56.

Benbenishty, R., \& Astor, R. A. (2005). School violence in context: Culture, neighborhood, family, school, and gender. Oxford University Press. https://doi.org/10.1093/acprof:oso/9780195157802.001.0001

Binbaşıŏlu, (2000). Okulda ders dışı etkinlikler. İstanbul: Milli Eğitim Bakanlığı Yayınları

Bingham, A. (2004). Çocuklarda problem çözme yeteneklerinin geliştirilmesi. (Çev. A. F. Oğuzkan). İstanbul: Milli Ĕgitim Bakanlığı Yayınları.

Binkley, M., Erstad, O., Herman, J., Raizen, S., Ripley, M., \& Rumble, M. (2010). Draft white paper 1: Defining 21st century skills. Available online also at: http://cms. education. gov. il/NR/rdonlyres/19B97225-84B1-4259-B423-698E1E8171A/115804/defining21stcenturyskills. pdf [accessed in Kota Kinabalu, Malaysia: April 15, 2015].

Brown, L. J. (1988). Helping children learn to solve problems. Day Care and Early Education. Cilt, 6(22), 26-30. https://doi.org/10.1007/BF01622980

Bulut, N. (2006). Bir grup üniversite öğrencisinin demokratik tutumları ile çeşitli değişkenler arasındaki ilişkiler. Kuram ve Uygulamada Ë̆itim Yönetimi, 45(45), 37-59.

Button, D. M. (2008). Social disadvantage and family violence: Neighborhood effects on attitudes about intimate partner violence and corporal punishment. American Journal of Criminal Justice, 33, 130-147. https://doi.org/10.1007/s12103-008-9033-3

Capp, G., Moore, H., Pitner, R., Iachini, A., Berkowitz, R., Astor, R. A., \& Rami Benbenishty, R. (2017). School violence. Oxford Research Encyclopedia of Education, 1-22. https://doi.org/10.1093/acrefore/9780190264093.013.78

Cedefop. (2014). Terminology of European education and training policy (Second Edition) - A selection of 130 key terms. Luxembourg: Publications Office. Retrieved from www.cedefop.europa.eu/EN/Files/4117_en.pdf

Çekici, F., \& Güçray, S. S. (2012). Problem çözme terapisine dayalı beceri geliştirme grubunun üniversite öğrencilerinin sosyal problem çözme becerileri öfkeyle ilişkili davranış ve düşünceler ile sürekli kaygı düzeylerine etkisi. Çukurova Üniversitesi Sosyal Bilimler Enstitüsü Dergisi, 21(2).

Cengiz, S., \& Ercan, L. (2011) Ergenlerde saldırganlık ve problem çözme becerileri arasındaki ilişki, XI. Ulusal Psikolojik Danışma ve Rehberlik Kongresi, (3-5 Ekim).

Çeşit, C., Ece, A. S., \& Kafadar, H. (2012). Sanat eğitimi alan ve almayan lise öğrencilerinin problem çözme becerileri ve benlik saygısı düzeylerinin incelenmesi (Bolu ili örneği). International Online Journal of Educational Sciences, 4(3), 706-726.

Çevik, D. B. (2011). Müzik öğretmeni adaylarının çeşitli değişkenlere göre problem çözme becerileri, Kastamonu Eğitim Dergisi 19 (3), 1003-1012.

Çevik, D. B., \& Özmaden, M. (2013). Ö̈̆retmen adaylarının problem çözme becerileri. Ĕğitim ve Öğretim Araştırmaları Dergisi, 2(3), 270-275.

Chaffin, M. (2006). The changing focus of child maltreatment research and practice within psychology. Journal of Social Issues, 62, 663-684. https://doi.org/10.1111/j.1540-4560.2006.00482.x

Chang, E. C., D'Zurilla, T. J., \& Sanna, L. J. (2004). Social problem solving: Theory, research, and training. American 
Psychological Association. https://doi.org/10.1037/10805-000

Copeland-Linder, N., Johnson, S. B., Haynie, D. L., Chung, S. E., \& Cheng, T. L. (2012). Retaliatory attitudes and violent behaviors among assault-injured youth. Journal of Adolescent Health, 50(3), 215-220. https://doi.org/10.1016/j.jadohealth.2011.04.005

Danışık, N. D. (2005). Ergenlerin sürekli öfke öfke ifade tarzları ile problem çözme becerileri arasındaki ilişki. Yüksek Lisans Tezi, Abant İzzet Baysal Üniversitesi Sosyal Bilimler Enstitüsü, Bolu.

Davis, M. (2010). Practicing in democracy in the NCLB Elementary classroom. Master thesis, Domanician University of California, San Rafael, CA.

Debarbieux, E. (2009). Okulda şiddet: Küresel bir tehdit (Çev.: İsmail Yergüz). İstanbul: İletişim Yayınları, 2009, s.108

Demir S. (2017). Ergenlerin kişilerarası problem çözme becerileri ve empatik ĕ̆ilimlerinin sahip oldukları değerler açısından incelenmesi, Yüksek Lisans Tezi. İstanbul Sabahattin Zaim Üniversitesi, Sosyal Bilimler Enstitüsü, İstanbul.

Diker, Z. (2012). Demokrasi eğitimi ve lise öğrencilerinin demokratik davranışları üzerine bir araştırma. Eğitim ve ögretim araştırmaları dergisi, 1(3), 229-238.

Doğanay, A., Çuhadar, A., \& Sarı, M. (2004). Sosyal bilgiler ve sınıf öğretmenlerinin demokrasi anlayışlarına ilişkin algılarının değerlendirilmesi. Uluslararası Demokrasi Eğitimi Sempozyumu, 20, 21.

Dostál, J. (2015). Theory of problem solving. Procedia-Social and Behavioral Sciences, 174, 2798-2805. https://doi.org/10.1016/j.sbspro.2015.01.970

Durmuş, E. (2013). Ergen bakış açısıyla okulda şiddet ve çözüm önerileri. E-International Journal of Educational Research, 4(3), 41-57.

D'zurilla, T. J., Chang, E. C., \& Sanna, L. J. (2003). Self-esteem and social problem solving as predictors of aggression in college students. Journal of Social and Clinical Psychology, 22(4), 424-440. https://doi.org/10.1521/jscp.22.4.424.22897

D'Zurilla, T. J., Nezu, A. M., \& Maydeu-Olivares, A. (2004). Social Problem Solving: Theory and Assessment. Theory and Assessment (Edited by Chang, E.C., D'Zurilla,T.J. And Sanna, L. J, 2004), American Psychological Association, Washington. https://doi.org/10.1037/10805-001

Edgington, W. D. (2001). Solving problems with twenty questions. Social Education, 65(6), 379-381.

Elkatmış, M., \& Toptaş, V. (2015). Sınıf Öğretmeni Adaylarının Demokratik Tutumlarının İncelenmesi, YYÜ Ĕ̆itim Fakültesi Dergisi (YYU Journal Of Education Faculty) 8(I), 128-144.

Flannery, D. J. (1997). School Violence: Risk, Preventive Intervention, and Policy. Urban Diversity Series, No. 109.

Fowler, P. J., Tompsett, C. J., Braciszewski, J. M., Jacques-Tiura, A. J., \& Baltes, B. B. (2009). Community violence: A meta-analysis on the effect of exposure and mental health outcomes of children and adolescents. Development and Psychopathology, 21, 227-259. https://doi.org/10.1017/S0954579409000145

Gafoor, K. A. (2015). Validation of Scale of Commitment to Democratic Values among Secondary Students. Online Submission, 3(1), 361-373.

Genç, S. Z., \& Kalafat, T. (2007). Öğretmen adaylarının demokratik tutumları ile problem çözme becerilerinin çeşitli değişkenler açısından incelenmesi.. Pamukkale Üniversitesi Eğitim Fakültesi Dergisi, 22(22), 10-22.

Gençoğlu, C., Kumcağız, H., \& Ersanlı, K. (2014). Ergenlerin şiddet eğilimine etki eden ailevi faktörler. Electronic Turkish Studies, 9(2), 639-652. https://doi.org/10.7827/TurkishStudies.6208

Greiff, S, Holt, D., \& Funke, J. (2013). Perspectives on problem solving in educational assessment: analytical, interactive, and collaborative problem solving. The Journal of Problem Solving, 5, 71-91. https://doi.org/10.7771/1932-6246.1153

Grunseit, A. C., Weatherburn, D., \& Donnelly, N. (2005). School violence and its antecedents: Interviews with high school students. NSW Bureau of Crime Statistics and Research.

Güçray, S. (2003). The Analysis of Decision Making Behaviour and Perceived Problem Solving Skills in Adolescents. The Turkish Online Journal of Educational Technology, 2(2), 2003.

Güngör, M. (2013). Öğretmen adaylarının problem çözme becerisinin sosyo ekonomik yapı, aile tipi ve aile tutumları ile ilişkisinin incelenmesi. Kastamonu Eğitim Dergisi, 21(3), 1071-1088.

Guttman, M., Mowder, B. A., \& Yasik, A. E. (2006). The ACT against violence training program: A preliminary 
investigation of knowledge gained by early childhood professionals. Professional Psychology: Research and Practice, 37, 717-723. https://doi.org/10.1037/0735-7028.37.6.717

Güven, M. (2010). An analysis of the vocational education undergraduate students' levels of assertiveness and problem-solving skills. Procedia-Social and Behavioral Sciences, 2(2), 2064-2070. https://doi.org/10.1016/j.sbspro.2010.03.282

Güven, S. (2009). Demokrasi eğitimi. İç. Turan, Refik ve Ali Murat Sünbül, ed. Sosyal bilgiler öğretiminde yeni yaklaşımlar. Ankara, Pegem A yayıncılık.

Hamarta, E. (2009). A prediction of self-esteem and life satisfaction by social problem solving. Social behavior and personality: an international journal, 37(1), 73-82. https://doi.org/10.2224/sbp.2009.37.1.73

Hawkins, J. D., Herrenkohl, T. I., Farrington, D. P., Brewer, D., Catalano, R. F., Harachi, T. W., \& Cothern, L. (2000, April). Predictors of youth violence. Juvenile Justice Bulletin, 1-11. https://doi.org/10.1037/e524202006-001

Heppner, P. P., \& Baker, C. E. (1997). Applications of the Problem Solving Inventory. Measurement and Evaluation in Counseling and Development, 29(4), 229-241. https://doi.org/10.1080/07481756.1997.12068907

Heppner, P. P., Witty, T. E., \& Dixon, W. A. (2004). Problem-solving appraisal and human adjustment: A review of 20 years of research using the Problem Solving Inventory. The Counseling Psychologist, 32(3), 344-428. https://doi.org/10.1177/0011000003262793

Huesmann, R. L. (2007). The impact of electronic media violence: Scientific theory and research. Journal of Adolescent Health, 41, S6-S13. https://doi.org/10.1016/j.jadohealth.2007.09.005

Irshadullah, H. M., \& Inamullah, H. M. (2016). Democracy and Social Responsibility at Secondary Level in Khyber Pakhtunkhwa. Dialogue (1819-6462), 11(1).

Kabasakal, K. A., Şahin, S. G., Kelecioğlu, H., Gelbal, S., Atar, B., \& Doğan, N. (2015). Lise öğrencilerinin demokratik okul kültürü algılarının incelenmesi, Kuram ve Uygulamada Egitim Yönetimi Dergisi, 21(2), 247-270.

Kalayc1, N. (2006). Problem çözme. Öğretim ilke ve yöntemleri, (F. Dilek Gözütok). Ankara: Ekinoks Eğitim Danışmanlık Hizmetleri ve Basın Yayın Dağıtım San. Ltd. Şti,

Karababa, A., \& Dilmaç, B. (2015). Ergenlerde insani değerlerin sürekli öfke ve öfke ifade biçimlerini yordamadaki rolü. İlkögrretim Online, 14(3). https://doi.org/10.17051/io.2015.85927

Karahan, T. F., Sardoğan, E. M., Özkamalı, E., \& Dicle, N. A. (2006). Öğretmen adaylarında demokratik tutum, nevrotik eğilimler ve kendini gerçekleştirme. Hacettepe Üniversitesi Eğitim Fakültesi Dergisi, 30(30).

Karaman-Kepenekci, Y. (2006). A Study of university students' attitudes towards children's rights in Turkey. The International Journal of Children's Rights, 14(3), 307-318. https://doi.org/10.1163/157181806778458095

Karasar, N. (2012). Bilimsel araştırma yöntemi (24. baskı). Ankara: Nobel Yayıncılık.

Kılıç, D., Ercoşkun, M. H., \& Nalçacı, A. (2004). Sınıf öğretmeni adaylarının demokratik tutumları, Türkiye Sosyal Araştırmalara Dergisi, 2-3.

Kim, H. K., \& Capaldi, D. M. (2004). The association of antisocial behaviour and de- pressive symptoms between partners and risk for aggression in romantic relationships. Journal of Family Psychology, 18, 82-96. https://doi.org/10.1037/0893-3200.18.1.82

Kıncal, R. Y., \& Işık, H. (2003). Demokratik eğitim ve demokratik değerler. Eğitim Araştırmaları, 3(11), 54-58.

Koç, B., \& Kavas, A. B. (2015). Üniversite öğrencilerinin saldırganlık, kişilerarası problem çözme becerileri, kişilerarası ilişki tarzları ve iletişim beceri arasındaki ilişkilerin incelenmesi. Uluslararası Türkçe Edebiyat Kültür Eğitim (TEKE) Dergisi, 4(2), 783-799. https://doi.org/10.7884/teke.491

Koç, C. (2016). İlköğretim öğrencilerinin problem çözme becerilerine yönelik algıları ve öğrenme sürecinde yardım istemeleri Kastamonu Ĕ̈itim Dergisi, 23(2), 659-678.

Koray, Ö., \& Azar, A. (2008). Ortaöğretim öğrencilerinin problem çözme ve mantıksal düşünme becerilerinin cinsiyet ve seçilen alan açısından incelenmesi. Kastamonu Ĕ̆itim Dergisi, 16(1), 125-136.

Korkut, F. (2003). Saldırganlık düzeyleri farklı lise öğrencilerinin stresle başa çıkma yolları. Psikiyatri Psikoloji Psikofarmakoloji Dergisi, 11(4), 279-288.

Kurtyılmaz, Y. (2005). Öğretmen adaylarının saldırganlık düzeyleri ile akademik başarıları, iletişim ve problem çözme becerileri arasındaki ilişkiler. Yayınlanmamış Yüksek Lisans Tezi. Anadolu Üniversitesi, Eğitim Bilimleri Enstitüsü, Eskişehir. 
Kuş, Z., \& Çetin, T. (2014). İlköğretim öğrencilerinin demokrasi algıları. Kuram ve Uygulamada Eğitim Bilimleri, 14(2), 769-790.

Larose, S., \& Tarabulsy, G. M. (2015). Academically at-risk students. In David L. DuBois and Michael J. Karcher (Eds). Handbook of Youth Mentoring, 440-453. (2nd ed.). New York : Sage Publications. https://doi.org/10.4135/9781412976664.n29

Linde, J., \& Ekman, J. (2003). Satisfaction with democracy: A note on a frequently used indicator in comparative politics. European journal of political research, 42(3), 391-408. https://doi.org/10.1111/1475-6765.00089

Maddoux, J., Symes, L., McFarlane, J., Koci, A., Gilroy, H., \& Fredland, N. (2014). Problem-solving and mental health outcomes of women and children in the wake of intimate partner violence. Journal of environmental and public health, Article ID 708198, 7 pages. https://doi.org/10.1155/2014/708198

Mian, M. (2005). World Report on Violence and Health: What It Means For Children and Pediatricians. The Journal of Pediatrics, 145, 14-19. https://doi.org/10.1016/j.jpeds.2004.03.054

Moller, J. (2006). Democratic schooling in Norway: implications for leadership in practice. Leadership and Policy in Schools, 5(1), 53-69. https://doi.org/10.1080/15700760500498779

Moon, J. R., \& Eisler, R. M. (1983). Anger control: An experimental comparison of three behavioral treatments. Behavior Therapy, 14(4), 493-505. https://doi.org/10.1016/S0005-7894(83)80073-2

Nader, K. (2010). Children's and adolescents' exposure to the mass violence of war and terrorism: Role of the media. In N. B. Webb \& K. J. Doka (Eds.), Helping bereaved children: A handbook for practitioners (3rd ed., pp. 215-239). New York, NY: Guilford Press.

Nazıroğlu, B., \& Çetin, M. (2014). Yüksek Din Eğitimi Öğrencilerinin Demokratik Tutumları Üzerine Bir İnceleme. Hitit Üniversitesi İlahiyat Fakültesi Dergisi, 13(25), 57-91. https://doi.org/10.14395/jdiv109

Norrıs, Pippa. (2011), Democratic deficit. Critical citizens revisited. New York: Cambridge University Press.

OECD (Organisation for Economic Co-operation and Development). (2003). Key competencies for a successful life and well-functioning society. The definition and selection of key competencies: Executive summary. Summary of report by S.D. Rychen \& L.H. Salganik (Eds.). Göttingen: Hogrefe and Huber Publishers. Retrieved from www.oecd.org/dataoecd/47/61/35070367. pdf

Ögülmüs, S. (2001). Kisilerarasi sorun çözme becerileri ve egitimi. Ankara: Nobel Yaymlan.

Özgür, G., Yörükoğlu, G., \& Baysan-Arabacı, L. (2011). Lise öğrencilerinin şiddet algıları, şiddet eğilim düzeyleri ve etkileyen faktörler. Psikiyatri Hemşireliği Dergisi, 2(2), 53-60.

Öztaban, Ş., \& Adana, F. (2015). Lise öğrencisi erkek ergenlerde problem çözme eğitiminin; problem çözme becerisi, kişilerarası ilişki tarzı ve öfke kontrolü üzerine etkisi. Turkish Journal of Research \& Development in Nursing, 17(1).

Partnership for 21st Century Learning (P21). (2007). Framework for 21st century learning. http://www.p21.org/our-work/p21-framework adresinden 01.07.2018 tarihinde alınmıştır.

Saban, A. İ., \& Yüce, S. G. (2012). İlköğretim 6. 7. ve 8. sınıf öğrencilerinde problem çözme, bilişsel farkındalık ve epistemolojik inançlar. International Journal of Human Sciences, 9(2), 1402-1428.

Sağlam, A., \& İkiz, F. E. (2017). Ortaokul Öğrencilerinin Şiddet Eğilimleri İle Okula Bağl1lık Düzeyleri Arasındaki İlişkinin İncelenmesi. İlköğretim Online, 16(3). https://doi.org/10.17051/ilkonline.2017.330253

Sağlam, Ö. (2009). Orta öğretim kurumlarında yaşanan şiddet olgusu; Ankara Sincan örneğinde öğrencilerin eğitim önceliklerinin şiddet eğilimleri üzerindeki etkilerinin incelenmesi. Yayınlanmamış Yüksek Lisans Tezi. Ankara Üniversitesi, Sosyal Bilimler Enstitüsü, Ankara.

Sahin, N., Sahin, N. H., \& Heppner, P. P. (1993). Psychometric properties of the problem solving inventory in a group of Turkish university students. Cognitive Therapy and Research, 17(4), 379-396. https://doi.org/10.1007/BF01177661

Şam, E. A., Çaypınar, Y. L. İ., \& Alimcan, Y. L. D. (2016). Öğretmen adaylarının demokratik tutumları ve şiddete karşı tutumları arasındaki iliş̧ki (Amasya Üniversitesi Örneği). İstanbul Ĕgitimde Yenilikçilik Dergisi, 2(2), 31-53.

Saraçaloğlu, A. S., Uça, S., Baydilek, N. B., \& Coşkun, N. (2013). Öğretmen adaylarının demokratik tutumları ile değer algılarının incelenmesi. Adnan Menderes Üniversitesi Eğitim Fakültesi Ĕgitim Bilimleri Dergisi 4(1), 45-59.

Sardoğan, M. E., Karahan, T. F., \& Kaygusuz, C. (2006). Üniversite öğrencilerinin kullandıkları kararsızlık stratejilerinin problem çözme becerisi, cinsiyet, sınıf düzeyi ve fakülte türüne göre incelenmesi. Mersin Üniversitesi Eğitim 
Fakültesi Dergisi, 2(1), 78-97.

Sarıaltın, E., Ataizi, M. \& Server, N. S. (2017). Üniversite öğrencilerinin demokrasi algısı: geleneksel medya ve yeni medya ilişsisi, Anadolu Üniversitesi İletişim Bilimleri Fakültesi Uluslararası Hakemli Dergisi, 25(1), 1-16.

Serin, N. B., \& Derin, R. (2008). İlköğretim öğrencilerinin kişilerarası problem çözme becerisi algıları ve denetim odağı düzeylerini etkileyen faktörler. Uluslararası Ínsan Bilimleri Dergisi, 5(1), 1-18.

Sezen, G., \& Paliç, G. (2011, April). Lise öğrencilerin problem çözme becerisi algilarinin belirlenmesi. In 2 nd International Conference on New Trends in Education and Their Implications (27-29).

Sharma, M. H. K. (2015). İmportance of moral values in modern era. International Journal of Advencement in Engincering Technology, Management \& Applied Science, 2(7), 25-38.

Şişman, M., \& Dönmez, H. G. A. (2010). Demokratik bir okul kültürü için yeterlilikler çerçevesi. Uşak Üniversitesi Sosyal Bilimler Dergisi, 3(1), 167-182. https://doi.org/10.12780/UUSBD68

Slev, A. M. (2014). Perceptions of democracy and democratıc principles among romanian law students. Social-Behavioural Sciences, 1(73), 38-44.

Subba, D. (2014). Democratic values and democratic approach in teaching: A perspective. American Journal of Educational Research, 2(12A), 37-40. https://doi.org/10.12691/education-2-12A-6

Suleiman, M. F., \& Moore, R. (1996). Instilling Civic and Democratic Values in ALL Students: A Multicultural Perspectiv. 18p.; Portions of this paper presented at the National Social Sciences Association Conference, (Reno, NV, March).

Tamer, M. G. (2011). Okulların demokratik ve katılımcı öğrenim ortamlarına dönüştürülmesi (Demokratik Okul Yönetimi). Milli Eğitim Dergisi, 4l(192), 7-25.

Tekin, M., \& Güllü, M. (2010). Analysis of empathic artifice level of teacher candidates who study in the school of physical education and sport. Procedia-Social and Behavioral Sciences, 2(2), 1987-1992. https://doi.org/10.1016/j.sbspro.2010.03.269

Tekin, M., Yıldız, M., Lök, S., \& Taşğın, Ö. (2009). Beden eğitimi ve spor yüksekokulunda öğrenim gören öğretmen adaylarının çeşitli değişkenlere göre demokratik tutum düzeylerinin incelenmesi. Niğde Üniversitesi Beden Eğitimi ve Spor Bilimleri Dergisi, 3(3), 204-212.

Tkach, L. (2018). Social Development in Democratic Elementary-School Classrooms. https://steinhardt.nyu.edu/appsych/opus/issues/2013/spring/tkach adresinden 21.05.2018 tarihinde erişim sağlanmıştır

Ulusoy, K. (2007). Lise Tarih Programlarında Yer Alan Geleneksel ve Demokratik Değerlere Yönelik Öğrenci Tutumlarının ve Görüşlerinin Çeşitli Değişkenler Açısından Değerlendirilmesi, Doktora Tezi, Gazi Üniversitesi Eğitim Bilimleri Enstitüsü, Ankara.

Uzunkol, E. (2014). Hayat bilgisi öğretiminde uygulanan değerler eğitimi programının öğrencilerin özsaygı düzeyleri, sosyal problem çözme becerileri ve empati düzeylerine etkisi. Gazi Üniversitesi, Eğitim Bilimler Enstitüsü. Ankara.

Veugelers, W. (2010). Moral values in teacher education. International encyclopedia of education, 7, 650-655. https://doi.org/10.1016/B978-0-08-044894-7.00635-7

Wang, Y., Nomura, Y., Pat-Horenczyk, R., Doppelt, O., Abramovitz, R., \& Brom, D. et al. (2006). Association of direct exposure to terrorism, media exposure to terrorism, and other trauma with emotional and behavioral problems in preschool children. Annals of the New York Academy of Sciences, 1094, 363-368. https://doi.org/10.1196/annals.1376.051

Yaralı, K. T., \& Özkan, H. K. (2016). Çocukların (60-72 aylık) sosyal problem çözme becerileri ile sosyal yetkinlik ve davranış durumları arasındaki ilşikinin incelenmesi. Türkiye Sosyal Araştırmalar Dergisi, 2, 345-361.

Yazgan, A. D. (2013). Öğretmen adaylarının medya okuryazarlık düzeyleri ile aktif vatandaşllğa ilişkin demokratik değer düzeyleri arasındaki ilişski. Yayınlanmamış Doktora Tezi. Çanakkale Onsekiz Mart Üniversitesi, Eğitim Bilimleri Enstitüsü, Çanakkale.

Yazıcı, K. (2011). Sosyal Bilgiler Öğretmen Adaylarının Demokratik Değerlerinin Çeşitli Değişkenler Açısından İncelenmesi An Analysis of Social Studies Prospective Teachers' Democratic Values in Relation to Various Variables. Education, 36(159).

Yengin, D. (2010). Dijital oyunlarda şiddet kavramı: Yeni şiddet. Doktora Tezi, Marmara Üniversitesi, Sosyal Bilimler Enstitüsü, İstanbul. 
Yenice, N., Ozden, B., \& Evren, B. (2012). Examining of problem solving skills according to different variables for science teachers candidates. Procedia-Social and Behavioral Sciences, 46, 3880-3884. https://doi.org/10.1016/j.sbspro.2012.06.165

Yeşil, R. (2002). Okul ve Ailede İnsan Hakları ve Demokrasi Eğitimi, Ankara: Nobel Yayın Dağıtım.

Yıldırım, A., Hacıhasanoğlu, R., Karakurt, P., \& Türkleş, S. (2011). Lise öğrencilerinin problem çözme becerileri ve etkileyen faktörler. Uluslararası İnsan Bilimleri Dergisi, 8(1), 905-921.

Yıldırım, H. İ., \& Yalçın, N. (2008). Eleştirel düşünme becerilerini temel alan fen eğitiminin fen bilgisi öğretmen adaylarının problem çözme becerilerine etkisi. Gazi Üniversitesi Gazi Eğitim Fakültesi Dergisi, 28(3).

Yüksel, Ç. (2008). Üniversite ögrencilerinin kişiler arası ilişkilerinde yaşadıkları problemleri çözme becerilerinin belirlenmesi. Yüksek Lisans Tezi, Selçuk Üniversitesi, Sosyal Bilimler Enstitüsü, Konya.

\section{Copyrights}

Copyright for this article is retained by the author(s), with first publication rights granted to the journal.

This is an open-access article distributed under the terms and conditions of the Creative Commons Attribution license which permits unrestricted use, distribution, and reproduction in any medium, provided the original work is properly cited. 